\title{
The King is naked!
}

\author{
Carlos Germán Meza
}

${ }^{1}$ University of São Paulo, Institute of Energy and Environment, São Paulo, Brazil.

\begin{abstract}
In his latest book, Dr. Bjørn Lomborg (2020) criticizes the approach that some sectors of society have taken to climate change and proposes policies to address the problem. Dr. Lomborg is a renowned liberal pro-market environmentalist that acknowledges the existence of anthropomorphic climate change. Nevertheless, his analyses and proposals for tackling the problem are sparking heated debate among scholars and analysts. The book is the perfect invitation for readers to see the fierce and often covert ideological and economic struggles that arise as we respond to the climate, energy, and economic challenges facing humanity.
\end{abstract}

Keywords: Lomborg; climate change; energy transition; sustainability; contemporary capitalism.

Book reviewed: Lomborg, Bjorn. False Alarm. How climate change panic costs us trillions, hurts the poor, and fails to fix the planet. First edition. Hachette Book Group: New York, 2020.

São Paulo. Vol. 24, 2021

Review

DOI: http://dx.doi.org/10.1590/1809-4422asoc20200169vu2021L1RS 
In "False Alarm. How climate change panic costs us trillions, hurts the poor, and fails to fix the planet", a book by Dr. Bjorn Lomborg, the diagnosis is straightforward: we are doing a terrible job trying to solve our climate change predicaments. Neither the prevalent climate catastrophism (climate of fear) that some media is telling us is real nor the policies implemented until now are effective. Thus, we need to recognize our current limitations and address our climate and societal predicaments in a more practical, efficient, and effective way. Dr. Lomborg is a well-known liberal environmental writer that gained international recognition through a previous polemic book titled "The Skeptical Environmentalist" (2001) (1). In the new book, its critical and skeptical insights target what he considers the predominant climate change narrative and the climate and energy policies applied until now.

Most of the references used in the book are peer-reviewed papers. Moreover, the author referenced well-renowned economists such as the 2018 Nobel prize Prof. William Nordhaus. Nonetheless, it is proper to separate the positive and normative approaches that gave structure to the arguments exposed in the book. Regarding the description of our climate predicaments, Lomborg begins by providing several examples that show that most mass media (mainly in the USA) are not communicating the scientific evidence on climate change properly to the audience. Lomborg is not a denialist: "...Global warming [anthropogenic] is real, but it is not the end of the world. It is a manageable problem..." (p.11). However, he is against injecting baseless and counterproductive panic on the population.

It is curious, however, that if anthropogenic climate change is real -as the author repeatedly mentions in the book- the title "False alarm" is also sensationalist. Lomborg recognizes the alarm, but not the panic surrounded the phenomenon being alerted, which is different. In any case, renowned historian Yuval Harari indicates that "Panic [to terrorism] is a form of hubris. It comes from the smug feeling that I know exactly where the world is heading - down. Bewilderment is more humble, and therefore more clear sighted (2)." Thus, we should agree with Lomborg and Harari: we must switch off panic mode. Fear is not the correct answer for denialism or complete environmental alienation.

Lomborg claims that politicians worldwide are rushing to propose expensive and ineffective climate policies or do little or nothing about climate change, especially in the USA. Nevertheless, there is a more dangerous political phenomenon that remains unexplored in the book. If denialism is dying and hysteria is growing, even the most conservative political sectors that once oriented their political and rhetorical strategies to deny anthropogenic climate change will modify their discourses. But in what direction? A well-known moniker to refer to leftist ideas (red) implanted in (green) environmentalism concerns is "watermelon politics" (green outside, red outside). Less notorious, but perhaps more dangerous in our political times, are "avocado politics" (green outside, brown inside) ${ }^{1}$ : a synergy between environmental concerns and reactionary, conservative,

1 - It is important to note that, in this case, we are considering avocados with a green peel. 
ethno-nationalist ideologies (3). This "syncretism" is growing globally ${ }^{2}$, and underdeveloped countries should look carefully at its advances.

It is essential to note a narrative technique in the organization of the book. After explaining why climate catastrophism is not correct, Lomborg proceeds to formulate the real contradiction: GDP growth is a desirable and inevitable path for him. Also, there is (and there will be) an inexorable trade-off between GDP, emissions, and global temperature. We should accept it and deal with it! In other words, Lomborg is not assuming naive dematerialization and decoupling hypotheses (e.g., someday, somehow, maybe technology will allow us to increase global GDP while the global energy and material use and emissions will decrease). Bringing these assumptions to the surface is essential to the debate, and we should recognize that to the author. However, I disagree with Lomborg in defending that only the global capitalist system -with its inherent inequality distribution of wealth and capital accumulation imperative- is (and will be) decisive for tackling climate change. The Fukuyamist view of capitalism as the end of history that Lomborg embraces is problematic if we are going to discuss the present and the future. Thus, supporting capitalism and GDP growth as a "realistic" assertion for the future is indeed a personal political statement about what Lomborg believes the future should be. Naturally, degrowth scholars (a "vocal minority" as Lomborg call them ${ }^{3}$ ), ecosocialists, and historians, in general, would disagree with him.

The section "How not to solve the climate" is the most robust part of the book. Lomborg claims that individual voluntarism has little impact on reducing global emissions (e.g., vegetarianism, individual electric mobility, not to use airplanes). Also, the green energy transition is a failure and, so, the Paris agreement. The author also considers that climate policies that reduce emissions will increase energy prices affecting the poor. Bombastic writing style aside, Lomborg has good points here: global systemic problems require global and coordinated measures. That is one of the reasons why nationalist "avocado politics" are a red herring. The energy transition narrative, understood as an unstoppable $100 \%$ renewable teleology (4), collides with the prevalent fossil fuel dominance (i.e., the share of fossil fuels in primary energy consumption was $84 \%$ in 2019 , and coal still is the dominant fuel to produce electricity) (5). Thus, we cannot be surprised that the estimated chances to meet climate goals are meagre (6), and the world is not on the right path to achieve the Sustainable Development Goals (7). There are trade-offs (8) and climate and environmental justice concerns that often go unnoticed when discussing sustainability and climate change (9). We cannot deny that despite all the efforts, the results are, at best, insufficient.

The normative and final part of the book is the more problematic one. Since capitalism and GDP growth are sacrosanct and trade-offs between GDP, emissions, and temperature are inexorable, the author recommends focusing on pragmatic policy options.

2 - "It is possible to protect the climate and borders," the new Prime Minister [of Austria], Sebastian Kurz proclaimed, as he announced that the coalition would unite "the best of both worlds" by mandating 100 percent renewable energy by 2030, banning Islamic headscarves, and detaining asylum seekers (3).

3 - Lomborg is a vocal minority too in the conventional environmental narrative. 
The solutions he offers are not new: global and increasing carbon taxes, more investment in $R \& D$ (in energy storage, nuclear power, carbon capture and storage (CCS), and geoengineering) to boost innovation. These proposals are provocative. He supports nuclear reactors because do not emit $\mathrm{CO}_{2}$ during electricity generation. In the case of CCS and geoengineering technologies, it might come to be cheap, effective, and safe options in the future. However, we can quickly critique these proposals to orient economic resources for $R \& D$ in these options. Nuclear power is expensive (11), potentially dangerous, and it is currently declining in the world (except in some countries such as China) (5). Also, the precautionary principle concerning CCS and geoengineering technologies has been relatively respected until now. Still, Lomborg's support for $R \& D$ investments in those contested technologies is coherent with the arguments developed throughout the book: we are failing, and capitalism is here to stay. Thus, we should essay technological options that might "work better" than existing ones (such as solar and wind) without disrupting the prevalent capitalist landscape.

In section 12, "Innovation: what is needed most," the author claims that oil saved the whales (whale oil was replaced by kerosene for lighting). Nevertheless, the opposite is correct: the rise of fossil fuels (mainly petroleum) increased whaling intensity (10). According to York, "The case of whaling highlights the limited potential for technological developments to help overcome environmental problems without concurrent political, economic, and social change that supports conservation." Ref. (10) (p.1). Though innovation is essential, it is not a panacea for our predicaments.

Recently, Prof. Joseph Stiglitz wrote a demoralizing review of Lomborg's work (12). Stiglitz considers the work as a "book that deserves to be panned [...]. It's nominally about air pollution. It is really about mind pollution." Lomborg replied recently on his LinkedIn site (13), and the debate is on fire. It is not the first time that Prof. Stiglitz takes part in an intense debate on sustainability issues. At the end of the XX century, he and Prof. Robert Solow debated with Herman Daly about sustainability economics: the Georgescu-Roegen versus Solow/Stiglitz debate (14-17). Briefly, Prof. Daly confronted these influential economists to fully assume the implications of the economic process as an entropic process. Stiglitz and neoclassical economists' arguments ended up being known as "weak sustainability" (i.e., manufactured capital can substitute natural capital, no limits to economic growth). On the contrary, Daly and several ecological economists' arguments are identified as "strong sustainability" (18).

Remarkably, Lomborg and Stiglitz are self-declared liberal market believers. However, if we look closely, Lomborg is undressing the current economic order of his weak sustainable clothes. "The King is naked. Take it easy. Adapt your minds to nudity and think about what the best solutions within the coordinates of contemporary capitalism are", Lomborg seems to tell us. Is Stiglitz's review (12) a virulent reaction to the scene of nudity displayed by Lomborg? Perhaps. In any case, for those who understand the ecological crisis as a structural phenomenon rooted in the industrial capitalist system dynamics (19), it does not make much of a problem to accept that the King is naked.

It would be interesting to know what Lomborg thinks about disruptive technolo- 
gies. For instance, how artificial intelligence (AI), Big Data, or biotechnologies might change our energy and climate landscapes. In sum, I recommend the book. Nevertheless, I strongly recommend seeing the ferocious -and often underground-ideological struggles in which energy, climate, and economic challenges unfold.

\section{Acknowledgments}

Thanks to all colleagues at the Centro de Análise, Planejamento e Desenvolvimento de Recursos Energéticos (CPLEN), Instituto de Energia e Ambiente, Universidade de São Paulo.

\section{References}

1. Lomborg B. The Skeptical Environmentalist Measuring the Real State of the World. First. New York: Cambridge University Press; 2001.

2. Harari YN. 21 Lessons for the 21st Century. London: VINTAGE; 2018.

3. Gilman N. The Coming Avocado Politics. What Happens When the Ethno-Nationalist Right Gets Serious about the Climate Emergency. The Breakthrough Institute. 2020 Feb; Available from: https://thebreakthrough.org/journal/no-12-winter-2020/avocado-politics

4. Clark P. The Big Green Bang: how renewable energy became unstoppable. The Financial Times. 2017 [cited 2018 Jan 25]. Available from: https://www.ft.com/content/44ed7e90-3960$-11 \mathrm{e} 7-\mathrm{ac} 89-\mathrm{b} 01 \mathrm{cc} 67 \mathrm{cfeec}$

5. BP. Statistical Review of World Energy 2020. London; 2020. Available from: https:// www.bp.com/content/dam/bp/business-sites/en/global/corporate/pdfs/energy-economics/statistical-review/bp-stats-review-2020-full-report.pdf?utm_source=BP_Global_GroupCommunications_UK_external\&utm_medium $=$ email\&utm_campaign $=11599394$ _Statistical Revi

6. Bovari E, Lecuyer O, Mc Isaac F. Debt and damages: What are the chances of staying under the $2^{\circ} \mathrm{C}$ warming threshold? Int Econ. 2018;155(October 2017):92-108. Available from: https://doi.org/10.1016/j.inteco.2018.02.002

7. Moyer JD, Hedden S. Are we on the right path to achieve the sustainable development goals? World Dev. 2020;127:104749. Available from: https://doi.org/10.1016/j.worlddev.2019.104749

8. Fuso Nerini F, Tomei J, To LS, Bisaga I, Parikh P, Black M, et al. Mapping synergies and trade-offs between energy and the Sustainable Development Goals. Nat Energy. 2018;3(1):10-5. Available from: http://dx.doi.org/10.1038/s41560-017-0036-5 
9. Sovacool BK, Dworkin MH. Global energy justice: Problems, principles, and practices. Cambridge University Press; 2014. p. 391.

10. York R. Why Petroleum Did Not Save the Whales. Socius Sociol Res a Dyn World. 2017;3:237802311773921.

11. Smil V. "Too Cheap to Meter" Nuclear Power Revisited. IEEE SPECTRUM. 2016. Available from: https://spectrum.ieee.org/energy/nuclear/too-cheap-to-meter-nuclear-power-revisited

12. Stiglitz JE. Are We Overreacting on Climate Change? The New York Times. 2020 Jul 16; Available from: https://www.nytimes.com/2020/07/16/books/review/bjorn-lomborg-false-alarm-joseph-stiglitz.html

13. Lomborg B. The New York Times' stunningly false and deceptive hit piece to preserve climate alarmism [Internet]. Linkedin. 2020 [cited 2020 Jul 30]. Available from: https://www. linkedin.com/pulse/new-york-times-stunningly-false-deceptive-hit-piece-preserve-lomborg

14. Daly HE. Georgescu-Roegen versus Solow / Stiglitz. Ecol Econ. 1997;22(3):269-70.

15. Stiglitz JE. Georgescu-Roegen versus Solow / Stiglitz. Ecol Econ. 1997;22(3):269-70.

16. Solow RM. Georgescu-Roegen versus Solow-Stiglitz. Ecol Econ. 1997 Sep; 22(3):2678. Available from: http://linkinghub.elsevier.com/retrieve/pii/S0921800997000815

17. Daly HE. Reply to Solow/Stiglitz. Ecol Econ. 1997 Sep; 22(3):271-3. Available from: https://www.sciencedirect.com/science/article/pii/S0921800997000864

18. Neumayer E. Weak versus Strong Sustainability. Exploring the Limits of two opposing paradigms. Second. Cheltenham, UK. Northampton, MA, USA: Edward Elgar; 2003.

19. Marques L. Pandemics, Existential and non-Existential Risks to Humanity. Ambient Soc. 2020;23. Available from: http://www.scielo.br/scielo.php?script=sci_arttext\&pid=S1414$-753 \times 2020000100911 \&$ tlng $=$ en 


\section{Carlos Germán Meza}

$\square$ mezagonzalez@usp.br

\cgmgcimp@gmail.com

ORCiD: https://orcid.org/ 0000000182695894
Submitted on: $21 / 08 / 2020$

Accepted on: 19/10/2020

2021;24e:0169

How to cite: MEZA, C.G. The King is naked! Ambiente \& Sociedade. São Paulo, v. 24, p. 1-07, 2021. 


\section{O Rei está nu!}

\section{Carlos Germán Meza}

São Paulo. Vol. 24, 2021

Resenha
Resumo: Em seu livro mais recente, o Dr. Bjørn Lomborg (2020) critica a abordagem que alguns setores da sociedade têm dado às mudanças climáticas e propõe políticas para enfrentar o problema. O Dr. Lomborg é um renomeado ecologista liberal e pró-mercado. Ele reconhece totalmente a existência de mudanças climáticas de origem antropogênico no livro, mas suas análises e propostas para lidar com o problema levantam acirrados debates entre acadêmicos e analistas. A obra é o convite perfeito para os leitores observarem as ferozes, e muitas vezes ocultas, lutas ideológicas e econômicas que surgem quando se trata de responder aos desafios climáticos, energéticos e econômicos que a humanidade enfrenta.

Palavras-chave: Políticas ambientais; áreas verdes; urbanização; biota urbana.

Como citar: MEZA, C.G. O Rei está nu! Ambiente $\&$ Sociedade. São Paulo, v. 24, p. 1-07, 2021.

DOI: http://dx.doi.org/10.1590/1809-4422asoc20200169vu2021L1RS 


\title{
iEl Rey está desnudo!
}

\author{
Carlos Germán Meza
}

São Paulo. Vol. 24, 2021

Resumen: En su libro más reciente, el Dr. Bjørn Lomborg (2020) critica

Revisiones

el enfoque que algunos sectores de la sociedad han adoptado ante el cambio climático y propone políticas para abordar el problema. El Dr. Lomborg es un reconocido ecologista liberal y pro-mercado. El autor reconoce plenamente la existencia del cambio climático de origen antropogénico en su libro, pero sus análisis y propuestas para abordar el problema suscitan acalorados debates entre académicos y analistas. La obra es la invitación perfecta para que los lectores observen las feroces y a menudo encubiertas luchas ideológicas y económicas, que surgen al momento de intentar dar respuesta a los desafíos climáticos, energéticos y económicos que enfrenta la humanidad.

Palabras-clave: Lomborg; cambio climático; transición energética; sustentabilidad; capitalismo contemporáneo

Como citar: MEZA, C.G. iEl Rey está desnudo! Ambiente Ambiente \& Sociedade. São Paulo, v. 24, p. 1-07, 2021.

DOI: http://dx.doi.org/10.1590/1809-4422asoc20200169vu2021L1RS 